\title{
Modelling of the energy use of ventilation air from the mines
}

\author{
Karol Sztekler ${ }^{1, a}$, Maciej Komorowski ${ }^{1}$ and Dawid Kot ${ }^{3}$ \\ ${ }^{1}$ A GH University, Faculty of Energy and Fuels, Mickiewicza Av. 30, 30-059 Krakow, Poland \\ ${ }^{3}$ Fluor S.A, Prymasa Stefana Wyszyńskiego 11, 44-101 Gliwice, Poland
}

\begin{abstract}
In this paper an attempt is a comprehensive presentation of the problem of methane emissions from ventilation air from the mines to the atmosphere and possible solutions are suggested. Methane is released during excavation work in coal mines is a big problem in terms of safety and environmental protection. At the same time, it is a further potential source of energy that has been not yet used on a larger scale [1]. In order to properly identify ventilation air methane as an energy source will be presented its properties and possible complications due to the nature of this type fuel. A very important part will also determine the methane potential from ventilation air in Poland [2]. The work provides an overview of available technology for methane utilization from ventilation air as a fuel. Important from the point of view of the rest of the work is presentation of catalytic flow-reversal reactor technology created in Poland. Main objective of the topic is the development and modeling of heat recovery system cooperating with the IUMK-1000 installation [3]. The premise is the electricity production and also heat for central heating when it is technically feasible and justified in economic terms. Different concepts of heat recovery are modeled by the IPSEPro software. Then an analysis of the efficiency and performance of the proposed system is carried out. Based on the results, an individual concepts cycle works were analyzed and assessed and the best solutions possible for implementation on an industrial scale is selected.
\end{abstract}

\section{Introduction}

Methane released during excavation work in the coal mines is a big problem in terms of occupational safety and environmental protection. At the same time it is a further potential source of energy that has not been used yet on a larger scale. Emission of methane from coal seams into the atmosphere is harmful to the environment. It is a greenhouse gas whose greenhouse effect potential according to the Third Report (2007 year) of IPCC (Intergovernmental Panel on Climate Change) is tens of times greater than the potential of carbon dioxide. GWP unit (called Global Warming Potential) determines the ability of the IR absorption of the Earth by the individual compounds, wherein the reference point is $\mathrm{CO}_{2}$ [13]. The most importance (share of total CBM) has methane included in the process of demethylation (firedamp), and ventilation air methane (VAM Ventilation Air Methane). Currently in Poland firedamp is largely used fuel, mainly in the cogeneration installations with gas piston engine located in the immediate vicinity to the mine. This fuel is a mixture of methane (from $22 \%$ to $95 \%$ concentrations), nitrogen, oxygen, carbon dioxide [4], and is classified as a low or medium quality fuel. In the case of ventilation air methane energy value is much lower. According to the Decree of the Minister of Economy [5], the methane concentration in the ventilation shafts is $0.75 \%$. According to data from the State Mining
Authority absolute methane-bearing, that is the sum of the emitted methane from coal seams per year, remained stable (approx. 830 million $\mathrm{m}^{3} \mathrm{CH}_{4}$ ) in recent years. Relative methane-bearing (the amount of methane per coal tonne) is also not subject to the higher fluctuations and is approx. $11 \mathrm{~m}^{3} \mathrm{CH}_{4} /$ tonne.

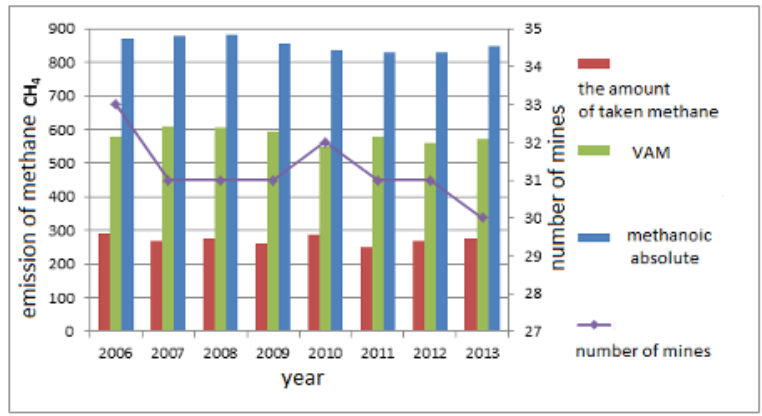

Figure 1. CH4 emission from coal mine [6]

Ventilation air methane in Poland is about $70 \%$ of the total methane emission from coal seams corresponding to 600 million $\mathrm{m}^{3}$ of methane emitted together with the removable ventilation air. In the world, excluding pilot plant and a small number of commercial installations, it is not used in any way and is the only source of harmful emissions.

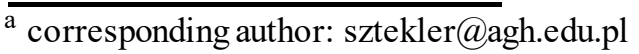




\section{Disposal methods of ventilation air methane}

In the last few years methods of methane disposal from ventilation air were developed. These technologies can be divided into two main groups [7]. In the first group VAM is used as combustion air, and can be regarded as a secondary fuel. This approach does not require significant changes to existing energy systems, but such use of ventilation air is limited by the distance of the ventilation shaft of the system and the required air flow. Devices that can be powered by ventilation air, as an additional fuel, include [7]:

- Internal combustion engines,

- Gas turbines,

- Power and industrial boilers

The air handling unit may be used as the main fuel. This group includes:

- Thermal flow reversal reactors,

- Catalytic flow reversal reactors,

- Gas turbines - turbines and microturbines of higher power (over 0.5 MW)

- Arrangement of the rotary kiln and a gas turbine.

It is also possible to use concentrators of methane to receive higher methane concentration in the gas, and then burning it for example in a gas turbine.

\subsection{Thermal flow-reversal reactors}

Thermal flow reversal reactor (Thermal Flow Reversal Reactor - TFRR) is a device, which is followed by cyclical processes of spontaneous combustion gas with a low concentration of methane. An example of such device is a VOCSIDIZER reactor units of Megtec Systems [14]. The main part of the TFRR is a heat exchanger in the form of a bed made of a ceramic material, together with the electrical system used to start-up. Start-up system consists in the ventilation air heating to a temperature of at least $1000{ }^{\circ} \mathrm{C}$, allowing oxidation of methane. Ventilation air of a suitable methane concentration $(0.3-1 \%)$ is injected into the reactor in one direction. Under the influence of the temperature, the methane oxidizes and flue gases radiate heat to the heat exchanger. At the same time the opposite side of the heat exchanger is heated and after the temperature reaches the desired one, the direction of gas flow is reversed. VAM fresh stream flowing through the bed, is heated up and in the central part begins to oxidize. The process takes place in a cyclic mood. TFRR reactor by itself can not directly use the energy content of methane in the ventilation air. Energy can be recovered from the hot gases discharged from the reactor. It is therefore necessary to apply heat exchanger, which makes it possible to recover energy from the flue gases. The reactor VOCSIDIZER at a VAM flow of 800 thousand $\mathrm{m}^{3} / \mathrm{h}$ of a $1 \%$ methane concentration is enough to get $72 \mathrm{MW}$ of heat that can be converted to $18 \mathrm{MW}$ electrical energy.

\subsection{Catalytic flow-reversal reactors}

The principle of the catalytic reactor in flow-reversal operation (CFRR) is similar to that used in TFRR. CFRR differs by using a catalyst which allows methane oxidation at lower temperatures (up to $350^{\circ} \mathrm{C}$ ).
This technology has been proposed by Canadian company CANMET. Pilot plant, as well as installations in the semi-industrial and industrial scale were built [8]. For a proper functioning of the device is required a minimum concentration of methane in the ventilation air, so low concentrations required mixing of VAM with other methane source.

\subsection{Gas Turbine}

There are several types of gas turbines allow for utilization of ventilation air. The first of these are the microturbines working on a mixture of air-methane at $\mathrm{CH}_{4}$ concentration less than $1 \%$. This solution was developed by Ingersoll Rand Energy Systems (now FlexEnergy in collaboration with Capstone Turbines). Ventilation air is compressed in the compressor then VAM goes to a recovery unit, which heats the flue gas and goes into the combustion chamber where it is possible to add the fuel needed to achieve the minimum operating parameters of the gas turbine [9]. Turbine MT250 has a nominal power of 250 $\mathrm{kW}$ and electrical efficiency of $30 \%$. The problem, as in most of the described devices is the need to supplie the minimum concentration of methane at about $1 \%$. The next type of turbines are microturbines for a gas with a low concentration with the catalytic combustion Production of such turbines with a capacity greater than $30 \mathrm{~kW}$ deals with Capstone Turbine Corporation and FlexEnergy [4]. Another possibility is the use of carbureted gas turbines (CGT) and carbureted catalytic gas turbine. As in the previous turbine a minimum concentration of methane in the ventilation air is required at a level of about $1 \%$.

\subsection{The arrangement of the rotary kiln and a gas turbine}

The arrangement of the rotary kiln and a gas turbine can utilize VAM as a main fuel. Depending on the characteristics of the ventilation air stream suitable low-quality coal amount is supplied into a rotary kiln. Coal waste and the ventilation air are moving in the same direction in the rotary kiln. Coal is combusted on the grate grid and heating the mixture of air and methane. At a temperature of about $1000{ }^{\circ} \mathrm{C}$ oxidation of methane occurs. The hot flue gases in the rotary kiln are directed to the heat exchanger where it heats the compressed air to the temperature of $900{ }^{\circ} \mathrm{C}$. Thus the heated air drives the gas turbine coupled to an electric generator. The first system was a pilot installation with a capacity of $1.2 \mathrm{MW}$ located in Queensland, Australia [7.8]. A country where most completed research installation and development work related to the potential use of VAM is Australia (Appin, Australia 2001, reactor VOCSIDIZER). Such initiatives are in Australia strongly supported by state institutions and this is a very important factor for such activity [7]. Extensive experience in the utilization of the ventilation air is also United Kingdom (UK Thoresby 1994, VOCSIDIZER reactor), which formed one of the first plant with a TFRR reactor. In addition to these countries attention should be paid also to the United States of America and China. In the USA (Windsor, USA, 2007) a wide range of investments related to the reduction of methane emissions into the atmosphere is realized, 
as in Australia. China is the country which has enormous potential in terms of both utilization of firedamp derived from methane drainage and ventilation air. In China (eg. Mine Duerping belonging to the Shanxi Coking Coal Group, 2013, Mine Da Tong in China, 2010) so far many installations where the fuel is VAM are created, and in addition a continuous increase in interest in these types of technologies has been observed. In Poland, as in other countries, actions to reduce methane emissions from coal mines into the air were also taken into action. Most of the investments in this area involve the use of gas piston engines. The fuel used in the power systems of this type is gas from coal mines demethanization. An innovative project, aimed at creation of technology that uses ventilation air exhaust shaft of coal mines as a fuel, is "Environmentally friendly utilization technology of methane from coal mines." The project was developed within the Innovative Economy Operational Programme and co-founded by the European Union. The main objective of the project was to develop technologies for the use of ventilation air with low concentration of methane to produce electricity and heat. The project developed a system with catalytic converter whose operating principle is described above.

The first stage of the project was to investigate the possibility of methane oxidation at concentration below of $1 \%$ in the presence of a catalyst. For this purpose, the laboratory IUMK-1 installation (Installation Methane Utilization of Mines) with thermal capacity of $1 \mathrm{~kW}$ th was built, which helped to determine the course of chemical processes and energy balance for the catalytic oxidation of methane [15]. In the IUMK-1 installation methane oxidation is at temperatures ranging from 350 to $600{ }^{\circ} \mathrm{C}$. The minimum concentration of methane in the ventilation air is $0.4 \%$. The efficiency of the chemical oxidation of methane, that is, the degree of methane conversion from the fuel, reached $97 \%$. The next stage of the project is the design and maintain a pilot scale installation with a thermal capacity up to $100 \mathrm{~kW}$. At this stage, the consortium cooperated with the potential recipient of the technology, which is Jastrzębskathe Coal Company. It was agreed the exact location of the installation is in the Jas-Mos Coal Mine. In the case of IUMK-100 installation methane oxidation starts at a temperature of $170{ }^{\circ} \mathrm{C}$. For the temperature of $380{ }^{\circ} \mathrm{C}$ methane oxidation efficiency is over of $90 \%$ [10].

On the basis of data obtained from the operation of IUMK-100 pilot plant, model of the whole IUMK-1000 system for $1 \mathrm{MW}_{\text {th }}$ with different variants of the energy use of flue gases was modeled by IPSEpro software of Simtech company.

\section{Systems of VAM energy use from IUMK-1000 installation}

Main objective of the topic is to develop a heat recovery system cooperating with the IUMK-1000 installation (figure 2). The premise is the production of electricity and also heat for central heating when it is technically feasible and justified in economic terms.

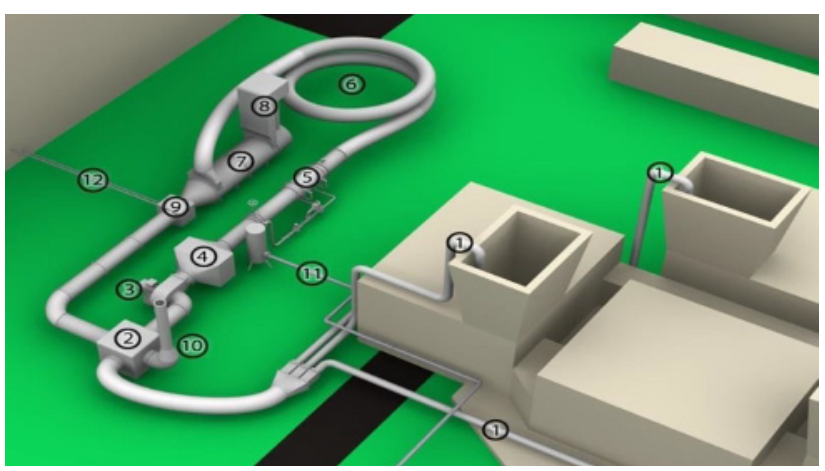

Figure 2. Scheme of installation for methane utilization UMK1000 : 1. Intake Air VAM, 2. Air dryer, 3. Fan, 4. Air Filter,5. Mixing of gases, 6. Buffer gas, 7. Gas-gas heat exchanger, 8. Catalytic reactor, 9. Gas-water heat exchanger, 10. Outlet gases, 11. Pipeline of methane, 12. Hot Water [4]

In the case of VAM disposal installations developed by the Methane Utilization of Mines Consortium heat source will be gases from the flow-reversal reactor at a temperature of $160{ }^{\circ} \mathrm{C}$ (or $500{ }^{\circ} \mathrm{C}$ after the system modification).

To develop the model following assumptions were adopted:

Table 1. Parametrs IUMK-1000 [4]

\begin{tabular}{|c|c|c|}
\hline Parametr & Value & - \\
\hline Stream mass VAM & 12.94 & $\mathrm{~kg} / \mathrm{s}$ \\
\hline Pressure VAM & 1.15 & $\mathrm{bar}$ \\
\hline $\begin{array}{c}\text { VAM temperature at the outlet of } \\
\text { GAS-GAS exchanger }\end{array}$ & 380 & ${ }^{\circ} \mathrm{C}$ \\
\hline $\begin{array}{c}\text { Flue gas temperature at the outlet } \\
\text { of the catalytic reactor }\end{array}$ & 500 & ${ }^{\circ} \mathrm{C}$ \\
\hline Useful thermal capacity & 1000 & $\mathrm{~kW}$ \\
\hline Methan concentration & 0.7 & $\%$ \\
\hline
\end{tabular}

Based on the assumptions of a Table 2 and IUMK-100 operation data base (Figure 3) system was developed by the Ipse Pro software.

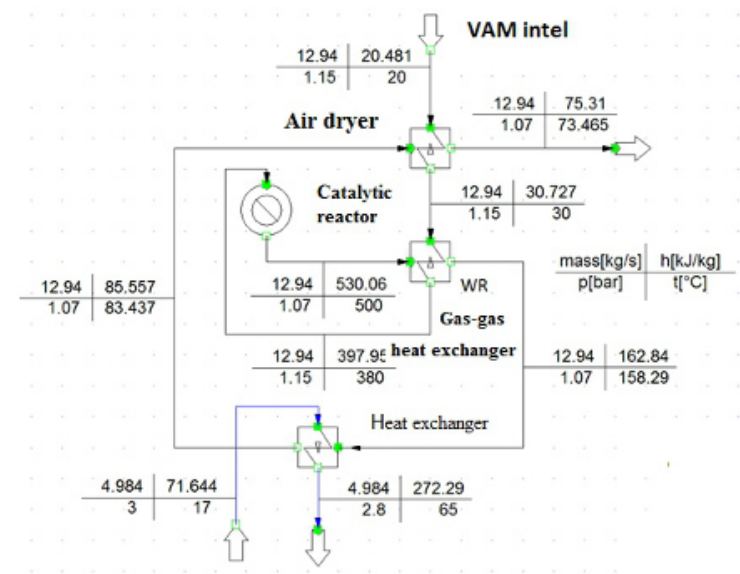

Figure 3. IUMK-100 scheme in IPSEpro software

Applicable technologies using the heat source at the low temperature:

- Steam cycle (Clausius-Rankine cycle) - classic steam cycle power plant, in which water is the thermodynamic factor (water vapor). 
It is justified to use steam cycle when the heat source temperature is at least at about $380{ }^{\circ} \mathrm{C}$ [11].

- ORC (Organic Rankine Cycle) - The principle of this cycle is the same as in the Clausius-Rankine cycle, excluding the thermodynamic factor, wherein the medium is low - boiling.

- Kalina cycle - is the cycle designed by Alexander Kalina in 1970. It is also a modification of the Clausius-Rankine cycle. In this case, the working medium is a mixture of water and ammonia [17].

- TFC systems (Trilateral Flash Cycle) - is a relatively new solution that enables the use of a dry or wet steam or hot water in the steam screw engine. The essential difference compared to the other cycles is to replace the steam evaporation of water, by a depressurization connected to the vaporising [18]

- Absorption Technologies and heat pumps - the use of absorption chillers for the purposes of air conditioning or heat pump equipment for the purposes of air conditioning and heating [16]

- The internal combustion engine - the use of an external heat source to drive a Stirling engine or a steam engine.

- Thermoelectric devices - are devices that use thermoelectric effect in semiconductor materials. In the present case it is possible to use the Seebeck effect, that is the formation of electromotive force in a cycle made of two metals or semiconductors, which connectors are located in the centers at different temperatures [12].

The rest of the work submitted for consideration will be the steam cycle and ORC cycle. This involves assumptions about the system designing and the limitations resulting from the use of other technologies.

The basic criterion is the ability to produce electricity and heat in combination with acceptable installation performance and effort. Moreover, the advantage of selected technologies should be their current use in reallife conditions and the possibility of basing on a certain experience of their operation.

\subsection{Analysis of the results}

The various concepts of heat recovery will be presented, and the results of the tests will be described and interpreted. Then an analysis of the efficiency and performance of the proposed system will be carried out. On their basis the best solutions will be selected. There were 2 variant simulations including ORC application and 1 steam cycle variant as a system for electricity production. For the case 1 (Fig. 4a, 4b) and the ORC cycle with R123 and R245fa as working medium.

In ORC unit for a cooling of condeneser water with parametrs $12 / 55{ }^{\circ} \mathrm{C}$ is used but in steam cycle for the cooling of heat exchanger (in this case heat exchanger serves as a condernser) water on parametrs $12 / 55^{\circ} \mathrm{C}$ is used. In the second case (Fig. 4c, 4d) of the ORC cycle, system is provided with an internal regeneration. Assumptions adopted as in case I, in addition to the system evaporator, turbine, condenser and pump also a regenerative heat exchanger is included.
Option 4e steam system realization requires IUMK1000 installation modification. This involves a low (approx. $101^{\circ} \mathrm{C}$ ) temperature of the flue gas leaving the gas-gas heat exchanger.

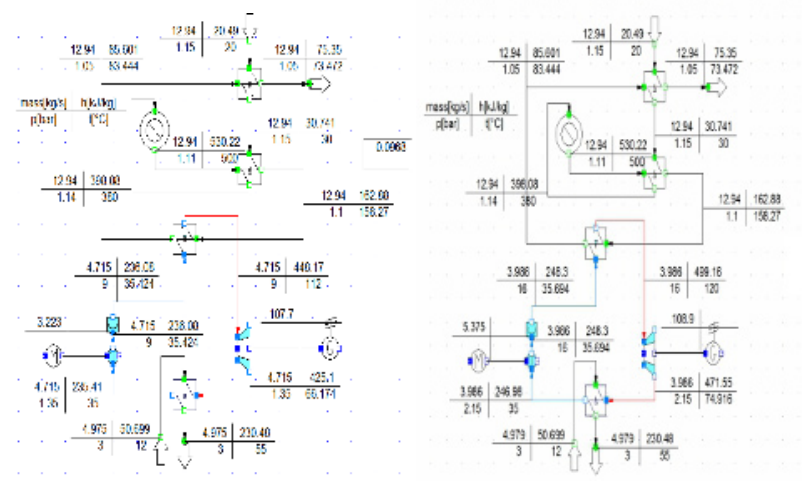

a) case I- R123

b)case I- R245fa
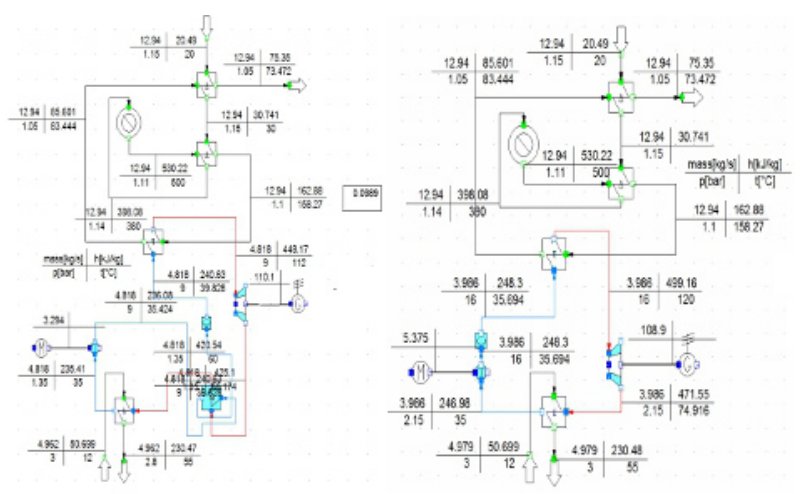

c)case II-R123

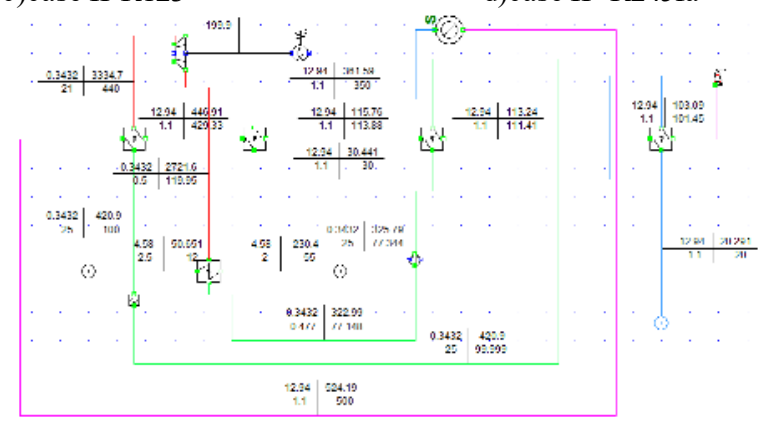

e) case III-steam cycle

Figure 4. Instalation for heat utylization from IUMK - 100

Higher steam parameters achieving at the outlet of the evaporator require offset of the WR heat exchanger behind the evaporator. Solution is shown in Figure $4 \mathrm{~d}$. In a modified version of the system flue gas releasing heat to the water in the evaporator have a initial temperature of $500{ }^{\circ} \mathrm{C}$, at the outlet of the evaporator approx. $430{ }^{\circ} \mathrm{C}$. Then the flue gases are supplied to the regenerative heat exchanger where heat the VAM to the desired temperature. In this way it is possible to obtain satisfactory performance of the steam and maintain autothermal operation. Steam system was modeled as ORC cycle, for one parameters cases of the cooling water $12 / 55^{\circ} \mathrm{C}$. The following parameters were applied for the vapor leaving the evaporator: steam temperature $-\mathrm{t}_{1}=440^{\circ} \mathrm{C}$, vapor pressure $-\mathrm{p}_{2}=60$ bar. The increased vapor pressure 
significantly improves the efficiency of the system. Cycle can be implemented at a pressure of 100 bar, but due to the scale of the investment, it is unlikely that the use of steam at such pressure. Fot the parameters selectionalso results from the WestVAMP system operating in Australia $\left(\mathrm{T}=450{ }^{\circ} \mathrm{C}, \mathrm{p}=58\right.$ bar) were taken into consideration.

Simulations were conducted for determining the suitability of individual cycles and their variants for heat recovery in IUMK-1000 system.

Table 2. Summary of the calculations results.

\begin{tabular}{|c|c|c|c|c|c|c|}
\hline & Case & Factor & $\begin{array}{c}\text { Regen } \\
\text { eratio } \\
\mathrm{n}\end{array}$ & $\begin{array}{c}\text { Cooling } \\
\text { water } \\
\text { parmaetrs } \\
{\left[{ }^{\circ} \mathrm{C}\right]}\end{array}$ & $\begin{array}{c}\eta_{\text {netto }} \\
{[\%]}\end{array}$ & $\begin{array}{c}N_{\text {el_nett }} \\
{[\mathrm{kW}]}\end{array}$ \\
\hline 1 & Ia & R123 & - & $12 / 55$ & 9.68 & 96.82 \\
\hline 2 & Ib & R245fa & - & $12 / 55$ & 9.56 & 95.64 \\
\hline 3 & IIc & R123 & + & $12 / 55$ & 9.89 & 98.93 \\
\hline 4 & IId & R245fa & + & $12 / 55$ & 10.16 & 106.35 \\
\hline 5 & IIIe & water & - & $12 / 55$ & 18.83 & 188.26 \\
\hline
\end{tabular}

The results of the thermodynamic cycles simulations lead to the conclusion that the most preferred one is the steam cycle with efficiency reaching $18.83 \%$. However, it requires substantial modification of the IUMK-1000 installation.

Cogeneration systems are able to achieve efficiency in the range from about $9.56 \%$ to $10.16 \%$. The hot air stream at a temperature of $500^{\circ} \mathrm{C}$ is much better and easier to convert the heat source than the air stream at a temperature of $160{ }^{\circ} \mathrm{C}$. Temperature of heat source determines the value of a exergy stream. Temperature increase causes an increase of exergy stream and at the same useful work results in decreased exergy efficiency.

\section{Summary}

Management of ventilation air methane from coal mines is a serious problem of coal mining. It should be considered both in terms of environmental protection and the economy. Methane leaving the shafts of mines contributes to adverse changes in the Earth's climate. Equally important it is the under-utilization of a very large number of potential fuel, which is VAM. Existing technologies allow for methane disposal from ventilation air are at an early stage of development and are facing many problems. The main barrier is in any case need to maintain the minimum required concentration of methane in a ventilation air stream. Often this condition can be met only by a VAM mix with available gas mining. Catalytic flow-reversal reactors are the most common methane utilization technology. VOCSIDIZER reactors work in many installations around the world and further investments are planned with their use. Despite the wide use of this technology it is still in the phase of development. Use of heat from the IUMK-1000 reactor is a basic problem of this work. Among the technologies that use low-temperature heat sources to produce electricity Rankine cycle with thermodynamic factors: water and R123 and R245fa organic mediums was choosen. Models of steam and ORC cycles using heat from the IUMK-1000 reactor were created by IPSEpro sotfware. The analysis shows that the most effective solution is to modify the installation and use of steam cycle (efficiency of $18.83 \%$ ). The efficiency of ORC cycle ranges from 9.5 to $10 \%$. Commisioning of the IUMK-1000 reactor plant and its performance over a longer time may allow for proper evaluation and assumptions revision for the heat recovery installation. The IUMK-1000 reactor can be a good solution for the problem of VAM in Polish coal mines.

\section{Acknowledgements}

The article was funded from government money Faculty of Energy and Fuels number 11.11.210.216

\section{References}

1. E. Mokrzycki, A. Uliasz-Bocheńczyk, Polityka energetyczna 9, 1 (2006)

2. N. A. Madlool, R. Saidur, M.S. Hossain, N.A. Rahim, Renew. Sust. Energ. Rev. 15, (2011)

3. A. Atmaca, R. Yumrutas, Appl. Therm. Eng. 66, (2014)

4. S. Nawrat, Uczelniane Wydawnictwa NaukowoDydaktyczne, Kraków (2009)

5. Rozporządzenie Ministra Gospodarki z dnia 28 czerwca 2002 r. w sprawie bezpieczeństwa i higieny pracy, prowadzenia ruchu oraz specjalistycznego zabezpieczenia przeciwpożarowego w podziemnych zakładach górniczych (Dz.U. 2002 nr 139 poz. 1169)

6. Wyższy Urząd Górnictwa, Stan bezpieczeństwa $i$ higieny pracy $w$ górnictwie $w 2012$ roku. Katowice (2013).

7. Assesment of the Worldwide Market Potential for Oxidizing Coal Mine Ventilation Air Methane. United States Environmental Protection Agency (2003)

8. Ventilation Air Methane (VAM) Utilization Technologies. United States Environmental Protection Agency (2010).

9. MT250 Series Microturbine. 250kW Continuous Onsite Electrical Power with Integrated Heat Recovery 2015 .

10. B. Stasińska, Katalityczne utlenianie metanu z powietrza wentylacyjnego kopalń. Towarzystwo Wydawnictw Naukowych Libropolis, Lublin (2014).

11. J. Duda, Dlaczego ORC jest najlepszym rozwiazaniem do wykorzystania energii odpadowej $w$ cementowni. Prace Instytutu Ceramini i Materiałów Budowlanych, nr 9, s. 32-43 (2012).

12. L.E Bell, Science, 321 (2008)

13. Forster, Climate Change 2007: The Physical Science Basis. Contribution of Working Group I to the Fourth Assessment Report of the Intergovernmental Panel on Climate Change. Cambridge University Press, Cambridge, United Kingdom and New York, NY, USA, s. 210 - 216 (2007).

14. VOCSIDIZER Regenarative thermal VOC oxidation, Materiały reklamowe producenta, MEGTEC Systems (2015).

15. S. Nawrat, S. Napieraj, AGH Journal of Mining and Geoengineering, 36, 3, Kraków (2013).

16. C.J. Ross, An overview of industrial waste heat recovery technologies for moderate temperatures less than $1000^{\circ} \mathrm{F}$. U.S. Department of Energy (2013). 
17. B. Saadatfar, R. Fakhrai, T. Fransson, The Journal of Macro Trends in Energy and Sustainability, 2, 1 (2014) 18. I.K. Smith, N. Stosic, C. Aldis, Trilateral flash cycle system. A high efficiency power plant for liquidresources. Materiały konferencji "World Geothermal Congress" (1995). 